\title{
Initial Plant Growth in Sand Mine Spoil Amended with Peat Moss and Fertilizer Under Greenhouse Conditions: Potential Species for Use in Reclamation
}

\author{
Todd A. Aschenbach, Elizabeth Brandt, Melissa Buzzard, Ryan Hargreaves, Thomas Schmidt, and \\ Amanda Zwagerman
}

\begin{abstract}
The Great Lakes Basin exhibits the largest collection of freshwater sand dunes in the world. Sand dunes are ecologically important and support a unique assemblage of flora and fauna. Sand dunes are also economically valuable. However, when sand dunes are mined, soil quality is drastically reduced. Therefore, soil quality improvements followed by revegetation maybe necessary for successful reclamation. This study evaluates the germination and initial growth of 2 legume species, sundial lupine (Lupinus perennis) and Illinois bundleflower (Desmanthus illinoensis), and 2 warm-season grass species, Indian grass (Sorghastrum nutans) and little bluestem (Schizachyrium scoparium), in the presence of 2 soil amendments (inorganic fertilizer and sphagnum peat moss) added to spoil from a local sand mine. We sowed species in pots and propagated them under greenhouse conditions. Results indicate that sundial lupine and Illinois bundleflower exhibited the greatest germination and growth among species. Peat moss had the greatest overall impact on germination and growth while the addition of fertilizer positively affected initial growth. Based on these results, sundial lupine is recognized as a primary candidate for sand mine reclamation, while Illinois bundleflower is also recommended as an appropriate species for revegetation efforts. We recommend using soil amendments that are functionally equivalent to peat in increasing soil water holding capacity. We further suggest that fertilization may be accomplished by including legumes in plant species mixes used for revegetation. Results presented here may help to identify appropriate species and soil amendments for the reclamation of former sand mines or restoration of freshwater sand dunes.
\end{abstract}

Keywords: Desmanthus, lupine, mine reclamation, sand dunes, soil amendments

$7^{\top}$ he Great Lakes Basin exhibits 1 the most extensive freshwater shoreline in the world, with Michigan containing the greatest amount at $4,912 \mathrm{~km}$ of the estimated 15,670 $\mathrm{km}$ total (U.S. Lake Survey 1952). Accordingly, the basin also exhibits the largest collection of freshwater dunes in the world (Albert 2000). Sand dunes in Michigan support a diverse flora and fauna including several rare, threatened, and endangered species such as Pitcher's thistle (Cirsium pitcheri), dwarf lake iris (Iris

Ecological Restoration Vol. 30, No. 1, 2012 ISSN 1522-4740 E-ISSN 1543-4079 C2012 by the Board of Regents of the University of Wisconsin System. lacustris), Houghton's goldenrod (Solidago houghtonii), and piping plover (Charadrius melodus; Albert 2000, Kost et al. 2010).

Sand dunes are also economically important for providing sand used in glass production, foundry molds, and road construction and maintenance (Ayres, Lewis, Norris and May, Inc. and Chapman 1978). In the United States, sand and gravel mining constitutes $48 \%$ of all mining operations (USDHHS 2008); 805 million metric tons of sand and gravel were mined in 2009 at a value of \$US6.8 billion (USGS 2010). Michigan is one of the leading sand and gravel producers in the nation, extracting 59 million metric tons in 2007 at a value of \$US265 million (USGS 2007).

Sand mining drastically reduces biodiversity and soil quality in sand dune ecosystems (Bowles et al. 1990, Cummings et al. 2005). Removal of vegetation during mining leads to soil erosion, loss of pre-disturbance soil, decreased soil organic matter, nutrients, and water holding capacity, and increased soil surface temperatures which inhibit plant establishment (Gaffney and Dickerson 1987, Reeder and Sabey 1987, Enright and Lamont 1992, Prosser and Roseby 1995).

Sand processing also produces a waste product known as spoil which consists primarily of unwanted sand particle sizes with small amounts of 
impurities (e.g., soil organic matter). Spoil is typically spread over disturbed areas prior to revegetation efforts (A. Slater, Standard Sand Co., Fairmont Minerals, Grand Haven, MI, pers. comm.).

Although some dune species will colonize previously mined lands, rates of succession in these areas are incredibly slow (Maun and Krajnk 1989, Bowles et al. 1990). Therefore, reclamation efforts involving soil quality improvements and revegetation are necessary in order to assist the recovery of degraded sand dunes (Pichtel et al. 1994, Choi and Pavlovic 1998, Cummings et al. 2005).

Previous research has shown that the addition of soil amendments including paper de-inking sludge, compost, and inorganic fertilizer positively affect plant germination and growth due to increases in nutrient and soil water availability (Maun and Krajnyk 1989, Choi and Pavolic 1998, Fierro et al. 1999, Curtis and Classen 2007). Among plant functional groups, warm-season grasses and legumes are recommended for sand mine revegetation based on their ability to tolerate the hot, dry, and infertile conditions often found in former sand and gravel mines (Gaffney and Dickerson 1987, MacDonald et al. 2003). Legumes exhibit the added benefit of atmospheric nitrogen fixation (Gaffney and Dickerson 1987, Palmgren 2000).

This study evaluates the germination and initial growth of 2 native legumes, sundial lupine (Lupinus perennis) and Illinois bundleflower (Desmanthus illinoensis), and 2 native warm-season grasses, Indian grass (Sorghastrum nutans) and little bluestem (Schizachyrium scoparium). We evaluated germination and growth in pots under the influence of 2 soil amendments (inorganic fertilizer and sphagnum peat moss) added to spoil from a local sand mine and propagated under greenhouse conditions. We chose species based on their ability to limit soil erosion, increase soil nitrogen via nitrogen fixation, and reported success in previous mine revegetation efforts (Jefferies et al. 1981, Gaffney and Dickerson 1987, Palmgren 2000). We chose spoil amendments based on their ability to improve soil quality through nutrient additions (fertilizer) and soil water retention (peat moss). Soil nitrogen is particularly important in the reestablishment of degraded plant communities because it enhances the capacity of the ecosystem to support a more complex community (Tilman 1988, Callaway 1995, Callaway and Walker 1997). We also considered commercial availability when choosing these species and amendments.

Our objectives were to: 1) determine which of the evaluated species exhibit the greatest germination success and biomass accumulation; and 2) identify which spoil amendments, if any, positively affect seed germination and initial plant growth. Although reclamation of former sand mines is required by federal, state and provincial law throughout the Great Lakes Basin (e.g., United States Surface Mining Control and Reclamation Act of 1977; Chapter NR 135, Wisconsin Administrative Code; Michigan Natural Resources and Protection Act 451 of 1994; Ontario Mining Act of 1990), relatively little guidance is afforded in the literature. This study is useful in identifying plant species that may be appropriate for revegetation efforts at the regional scale while also providing insight into spoil amendments and plant functional groups (i.e. warm-season grasses, legumes) that may be appropriate for sand mine reclamation efforts at the global scale.

\section{Methods}

\section{Study Species}

We evaluated sundial lupine, Illinois bundleflower, Indian grass, and little bluestem for their potential use in sand mine reclamation. All species are native to the Great Lakes Basin and adapted for growth in well-drained, medium to dry, infertile soils including sands (USDA-NRCS 2011). Although little bluestem and sundial lupine are found locally in sand dunes or similar habitats (e.g., sand prairies), Illinois bundleflower and Indian grass are not characteristic species in these habitats (Kost et al. 2010). Therefore, it is important to note that the species used in this experiment are evaluated for their potential use in sand mine reclamation and would not satisfy restoration goals where only species that are characteristic of sand dune plant communities are acceptable.

\section{Spoil}

We obtained sand mine spoil from the Standard Sand Co., Fairmont Minerals, Grand Haven, MI. Spoil pH was determined from a $1: 1$ spoil/deionized water solution using a mini lab pH meter (IQ Scientific Instruments Inc., Carlsbad, CA). Mean spoil $\mathrm{pH}$ in non-amended spoil was $8.2(\mathrm{H}+$ conc. $\left.=6.3 \times 10^{-9} ; N=7\right)$; mean spoil $\mathrm{pH}$ in spoil amended with peat was $6.2(\mathrm{H}+$ conc. $=6.3 \times 10^{-7} ; N=7$ ).

Spoil organic matter determination follows the Loss-On-Ignition method; samples were ignited in a muffle furnace for $5 \mathrm{~h}$ at $500^{\circ} \mathrm{C}$ (Nelson and Sommers 1996). Mean organic matter in non-amended spoil was $1.1 \%(N=$ $5)$; mean organic matter in spoil that contained peat was $5.2 \%(N=5)$.

Spoil nitrate $\left(\mathrm{NO}_{3}\right)$ was determined via ion chromatography (DIONEX DX 500 Chromatography System, Sunnyvale, CA) of an extraction from $15.0 \mathrm{~g}$ of spoil mixed with $100 \mathrm{ml}$ of $2 \mathrm{M} \mathrm{KCl}$ (Binkley and Vitousek 1991). Mean nitrate in non-amended spoil was $0.48 \mathrm{mg} / \mathrm{L}$ (range $=0.40-0.57$ $\mathrm{mg} / \mathrm{L} ; N=3$ ); mean nitrate in spoil amended with fertilizer only was 1.15 $\mathrm{mg} / \mathrm{L}($ range $=1.11-1.22 \mathrm{mg} / \mathrm{L} ; N$ $=3$ ); mean nitrate in spoil amended with peat only was $0.52 \mathrm{mg} / \mathrm{L}$ (range = $0.39-0.77 \mathrm{mg} / \mathrm{L} ; N=3$ ); mean nitrate in spoil amended with both peat and fertilizer was $1.31 \mathrm{mg} / \mathrm{L}$ (range = $1.28-1.34 \mathrm{mg} / \mathrm{L} ; N=3)$. 


\section{Experimental Design}

Growth of each species from seed in sand mine spoil, with or without sphagnum peat moss and inorganic fertilizer, was evaluated using a $2 \times 2$ factorial array of spoil amendments which resulted in the following treatments: +peat/+fertilizer, +peat/-fertilizer, -peat/+fertilizer, -peat/-fertilizer (control). Spoil and amendments were mixed and added to sterilized $90 \mathrm{~cm}^{2} \times 8 \mathrm{~cm}$-deep square pots. Total spoil and amendment volume was $400 \mathrm{ml}$. The +peat/fertilizer treatment received $200 \mathrm{ml}$ of spoil, 200 $\mathrm{ml}$ of sphagnum peat moss (Premier Horticulture Inc., Redhill, PA), and $0.6 \mathrm{~g}$ of 12-5-7 nitrogen-phosphorus-potassium (NPK) fertilizer (Ultra Vigoro Fertilizer, United Industries Corp, St. Louis, MO). The amount of fertilizer added corresponds to an application rate of $741 \mathrm{~kg} \mathrm{ha}^{-1}(88.9$ $\mathrm{kg} \mathrm{N}, 16.3 \mathrm{~kg} \mathrm{P}$, and $43.0 \mathrm{~kg} \mathrm{~K})$. The + peat/-fertilizer treatment consisted of $200 \mathrm{~mL}$ of spoil and $200 \mathrm{~mL}$ of peat. The -peat/+fertilizer treatment consisted of $400 \mathrm{~mL}$ of spoil and $0.6 \mathrm{~g}$ of fertilizer. The control treatment consisted of $400 \mathrm{~mL}$ of spoil only. Ten replicates of each treatment were used for each species for a total of 160 pots.

\section{Growth/Harvest}

Planting occurred on 19 January 2009. Seeds of sundial lupine and Illinois bundleflower were scarified with sandpaper and inoculated with Rhizobium spp. bacteria prior to planting. Sundial lupine seeds were coldmoist stratified for $3 \mathrm{~d}$ at $4^{\circ} \mathrm{C}$ in a $50 / 50 \mathrm{mix}$ of damp sand/seed prior to planting. Seeds of Indian grass and little bluestem did not receive any treatment prior to planting. Seeds of all species were obtained from Prairie Moon Nursery, Winona, MN. Five seeds of each species were planted at a depth of $1 \mathrm{~cm}$ in each pot. Each pot contained a piece of shade cloth at the bottom to prevent spoil loss during watering. Pots were placed on tables in a greenhouse at Grand Valley State University, Allendale, MI.
Each pot received $29 \mathrm{~mL}$ water/d for the first 3 wks followed by $105 \mathrm{ml}$ water/wk thereafter. Natural sunlight was supplemented with fluorescent grow lights to provide a total of $14 \mathrm{~h}$ of sunlight/day. The latter watering rate corresponds to the average weekly rainfall between April and August in Ottawa County, MI., while light exposure corresponds to the average day length between April and May in the area (Pregitzer 1972). The greenhouse was maintained at $22-24^{\circ} \mathrm{C}$ throughout the experiment, and we randomized the location of each pot throughout the greenhouse tables at each watering.

Plants were harvested on 23 March 2009. Extraction involved gently prying the plant and root ball from the spoil with the aid of a spoon. Roots were then rinsed with deionized water. After extraction, roots and shoots were separated, dried at $70^{\circ} \mathrm{C}$ for $48 \mathrm{~h}$, and weighed.

Percent germination was calculated as the total number of seedlings per pot, including zeros, divided by the number of seeds planted. Mean root, shoot, and total weight were calculated as the total weight per pot divided by the number of seedlings within each pot. Chi-square analysis indicated that root, shoot, and total biomass were not significantly affected by seedling density (root: $\chi^{2}=0.0015, d f=97, p>0.050$; shoot: $\chi^{2}=0.0084, d f=97, p>0.050$; total: $\left.\chi^{2}=0.0067, d f=97, p>0.050\right)$. Differences in species germination and biomass accumulation among spoil amendments for all species combined and among spoil amendments within each species were analyzed with a GLM univariate two-way analysis of variance (ANOVA) with peat and fertilizer as fixed factors. Analyses among species were analyzed using a one-way ANOVA. Tukey's honest significant difference test (HSD) was used for post-hoc comparisons. Data were square root transformed where appropriate in order meet assumptions of parametric statistical analysis (Sokal and Rolf 1995). A non-parametric two-way analysis of variance (ANOVA; Schreirer-RayHare) was used to examine differences in biomass among spoil amendments within each species for data that did not meet parametric assumptions despite transformations (Dytham 2003); a non-parametric Mann-Whitney $U$ test was used to examine differences in total biomass among species. SPSS 14.0 for Windows was used for all statistical analyses.

\section{Results}

Germination differed significantly among species when all treatments are combined $(F=15.942, d f=3,156$, $p<0.001)$. Similarly, root, shoot, and total biomass also differed significantly (root: $\chi^{2}=34.351, d f=3, \quad p<0.001$; shoot: $F=28.140, d f=3,94, p<0.001$; total: $\left.\chi^{2}=47.800, d f=3, p<0.001\right)$. Comparisons among species show that mean germination was highest for Illinois bundleflower at 39\% which was significantly greater than all other species ( $p<0.001$; Table 1$)$. Mean root, shoot and total biomass per plant for Illinois bundleflower was significantly greater than little bluestem $(p<0.001)$; mean shoot biomass was significantly greater than Indian grass $(p<0.050$; Table 2).

Sundial lupine exhibited the second highest overall germination success at 21\% (Table 1). Mean shoot biomass at $0.039 \mathrm{~g}$ and mean total biomass at $0.051 \mathrm{~g}$ were significantly greater than all other species $(p<0.001)$; mean root biomass for sundial lupine was significantly greater than Illinois bundleflower and little bluestem $(p<0.001$; Table 2).

Comparisons among treatments across all species show that peat positively affected germination. Mean seed germination was $25.3 \%$ with peat compared to $18 \%$ without peat $(F=4.478, d f=1,156, p<0.050)$. The addition of peat or fertilizer positively affected root, shoot and total biomass. Mean root biomass per plant was $0.011 \mathrm{~g}$ in the presence of peat compared to $0.006 \mathrm{~g}$ in its absence $(F=7.544, d f=1,94, p<0.010)$. Mean 
Table 1. Mean germination $(\% \pm 1 \mathrm{SE})$ among species and spoil amendment treatments. Treatment codes: $+\mathrm{P},+\mathrm{F}=$ addition of peat or fertilizer, respectively; $-\mathrm{P},-\mathrm{F}=$ absence of peat or fertilizer, respectively.

\begin{tabular}{lccccc}
\hline Species & Overall & $+\mathbf{P} /+\mathbf{F}$ & $+\mathbf{P} /-\mathbf{F}$ & $-\mathbf{P} /+\mathbf{F}$ & $-\mathbf{P} /-\mathbf{F}$ \\
\hline Lupinus perennis & $21 \% \pm 3.6$ & $22 \% \pm 3.6$ & $42 \% \pm 8.7$ & $8 \% \pm 5.3$ & $12 \% \pm 5.3$ \\
Desmanthus illinoensis & $39 \% \pm 3.4$ & $52 \% \pm 5.3$ & $40 \% \pm 6.7$ & $28 \% \pm 6.8$ & $36 \% \pm 7.2$ \\
Sorghastrum nutans & $14 \% \pm 2.5$ & $16 \% \pm 5.8$ & $4 \% \pm 2.7$ & $18 \% \pm 5.5$ & $20 \% \pm 4.2$ \\
Schizachyrium scoparium & $12 \% \pm 2.6$ & $16 \% \pm 7.2$ & $10 \% \pm 4.5$ & $8 \% \pm 4.4$ & $14 \% \pm 4.3$ \\
\hline
\end{tabular}

Table 2. Mean root, shoot, and total biomass per plant ( $\mathrm{g} \pm 1 \mathrm{SE}$ ) among species and spoil amendment treatments. Treatment codes: $+P,+F=$ addition of peat or fertilizer, respectively; $-P,-F=$ absence of peat or fertilizer, respectively.

\begin{tabular}{|c|c|c|c|c|c|}
\hline Species & Overall & $+\mathrm{P} /+\mathrm{F}$ & $+\mathrm{P} /-\mathrm{F}$ & $-\mathrm{P} /+\mathrm{F}$ & $-P /-F$ \\
\hline \multicolumn{6}{|l|}{ Lupinus perennis } \\
\hline Root & $0.012 \pm 0.001$ & $0.014 \pm 0.002$ & $0.010 \pm 0.002$ & $0.011 \pm 0.007$ & $0.012 \pm 0.002$ \\
\hline Shoot & $0.039 \pm 0.003$ & $0.048 \pm 0.003$ & $0.034 \pm 0.008$ & $0.041 \pm 0.001$ & $0.030 \pm 0.004$ \\
\hline Total & $0.051 \pm 0.004$ & $0.062 \pm 0.004$ & $0.045 \pm 0.009$ & $0.052 \pm 0.008$ & $0.041 \pm 0.005$ \\
\hline \multicolumn{6}{|l|}{ Desmanthus illinoensis } \\
\hline Root & $0.006 \pm 0.001$ & $0.007 \pm 0.001$ & $0.006 \pm 0.001$ & $0.005 \pm 0.001$ & $0.007 \pm 0.001$ \\
\hline Shoot & $0.020 \pm 0.001$ & $0.028 \pm 0.002$ & $0.018 \pm 0.002$ & $0.016 \pm 0.002$ & $0.016 \pm 0.002$ \\
\hline Total & $0.026 \pm 0.002$ & $0.035 \pm 0.003$ & $0.024 \pm 0.003$ & $0.021 \pm 0.003$ & $0.023 \pm 0.003$ \\
\hline \multicolumn{6}{|l|}{ Sorghastrum nutans } \\
\hline Root & $0.012 \pm 0.005$ & $0.032 \pm 0.016$ & $0.007 \pm 0.005$ & $0.008 \pm 0.004$ & $0.002 \pm 0.001$ \\
\hline Shoot & $0.014 \pm 0.004$ & $0.031 \pm 0.011$ & $0.006 \pm 0.004$ & $0.012 \pm 0.003$ & $0.005 \pm 0.001$ \\
\hline Total & $0.026 \pm 0.009$ & $0.061 \pm 0.027$ & $0.013 \pm 0.009$ & $0.020 \pm 0.007$ & $0.008 \pm 0.001$ \\
\hline \multicolumn{6}{|l|}{ Schizachyrium scoparium } \\
\hline Root & $0.003 \pm 0.001$ & $0.004 \pm 0.001$ & $0.003 \pm 0.001$ & $0.001 \pm 0.001$ & $0.003 \pm 0.001$ \\
\hline Shoot & $0.009 \pm 0.002$ & $0.016 \pm 0.003$ & $0.008 \pm 0.004$ & $0.005 \pm 0.003$ & $0.006 \pm 0.002$ \\
\hline Total & $0.012 \pm 0.002$ & $0.020 \pm 0.003$ & $0.011 \pm 0.004$ & $0.006 \pm 0.004$ & $0.009 \pm 0.002$ \\
\hline
\end{tabular}

shoot biomass was $0.028 \mathrm{~g}$ in the presence of peat and $0.026 \mathrm{~g}$ in the presence of fertilizer compared to $0.014 \mathrm{~g}$ and $0.017 \mathrm{~g}$ in the absence of peat or fertilizer, respectively (peat: $F=19.762$, $d f=1,94, p<0.001$; fertilizer: $F=5.763$, $d f=1,94, p<0.050$; Figure 1). Mean shoot:root ratio for plants growing in non-amended spoil was $2.70(N=26)$ and 3.66 for plants growing in spoil containing fertilizer $(N=48)$. Mean total biomass was $0.038 \mathrm{~g}$ in the presence of peat and $0.037 \mathrm{~g}$ in the presence of fertilizer compared to $0.019 \mathrm{~g}$ and $0.023 \mathrm{~g}$ in the absence of peat or fertilizer, respectively (peat: $F=16.157$, $d f=1,94, p<0.001$; fertilizer: $F=5.272$, $d f=1,94, p<0.050$; Figure 1).

Comparisons among treatments indicate that the germination of sundial lupine was positively affected by the addition of peat. Mean seed germination was $32 \%$ with peat and $10 \%$ without peat $(F=18.651, d f=1,36$, $p<0.001$; Table 1). However, mean root, shoot, and total biomass per plant were not significantly affected by the addition of any spoil amendment.

Illinois bundleflower germination was positively affected by peat, while peat and fertilizer interacted to positively affect shoot and total biomass. Mean seed germination was $46 \%$ with peat and $32 \%$ without peat $(F=4.594$, $d f=1,36, p<0.050$; Table 1). Mean shoot biomass per plant was $0.028 \mathrm{~g}$ in the presence of peat and fertilizer compared to $0.016 \mathrm{~g}$ and $0.017 \mathrm{~g}$, respectively, in their absence $(F=4.602$, $d f=1,31, p<0.050)$. Mean shoot biomass in the control was $0.016 \mathrm{~g}$. The presence of peat and fertilizer individually also had a positive effect on shoot biomass (+peat $=0.023 \mathrm{~g}$ vs . -peat $=0.016 \mathrm{~g}, F=11.842, d f=1,31$, $p<0.010 ;+$ fert $=0.022$ g vs. - fert $=$ $0.017 \mathrm{~g}, F=4.728, d f=1,31, p<0.050$ ). Mean total biomass was $0.035 \mathrm{~g}$ in the presence of peat and fertilizer compared to $0.022 \mathrm{~g}$ and $0.023 \mathrm{~g}$ in the absence of peat or fertilizer, respectively $(F=5.108, d f=1,31, p<0.050)$.
Mean total biomass in the control was $0.023 \mathrm{~g}$ for Illinois bundleflower. Peat alone increased mean total biomass $(+$ peat $=0.030 \mathrm{~g}$ vs. - peat $=0.022 \mathrm{~g}$, $F=7.435, d f=1,31, p<0.050$; Table 2).

Germination was similarly low for both Indian grass and little bluestem, and spoil amendments did not significantly affect the germination of either species (Table 1). Growth of Indian grass was positively affected by the addition of fertilizer, with mean shoot biomass per plant at $0.021 \mathrm{~g}$ with fertilizer compared to $0.005 \mathrm{~g}$ without fertilizer $(F=7.183, d f=1,18$, $p<0.050$; Table 2).

Little bluestem exhibited the lowest total biomass among species and was positively affected by the addition of peat. Mean shoot biomass was $0.012 \mathrm{~g}$ in the presence of peat compared to $0.006 \mathrm{~g}$ in its absence $(F=4.823$, $d f=1,13, p<0.050)$, while mean total biomass was $0.016 \mathrm{~g}$ in the presence of peat compared to $0.008 \mathrm{~g}$ in its absence $(F=5.439, d f=1,13, p<0.050$; Table 2$)$. 


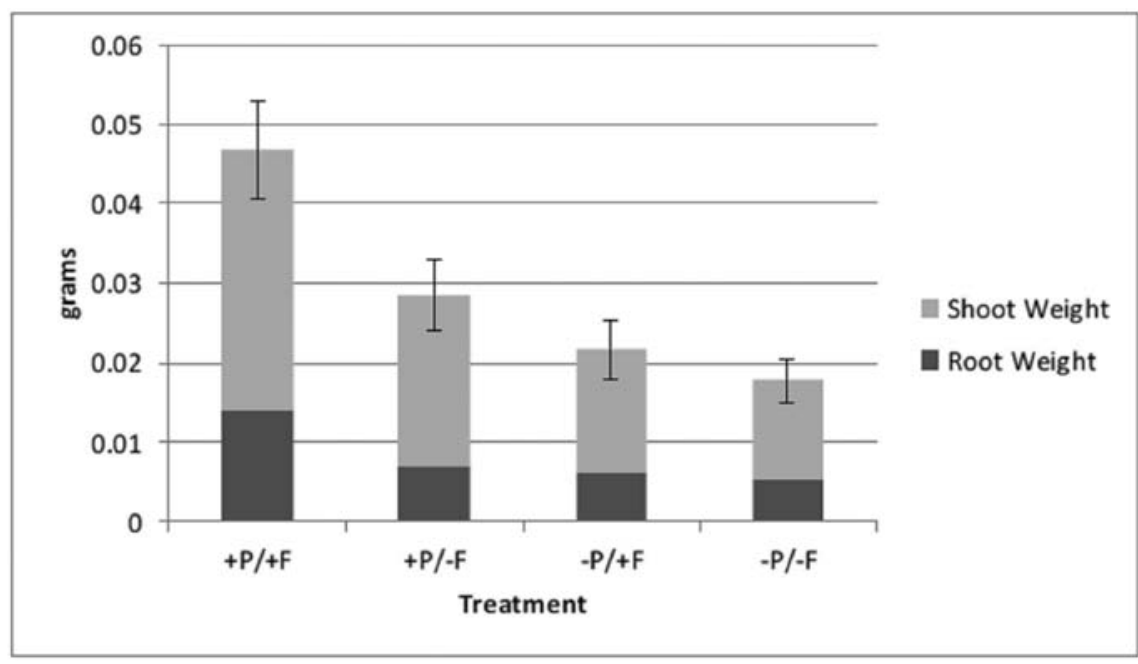

Figure 1. Mean root, shoot, and total biomass per plant ( $\pm \pm 1 \mathrm{SE}$ ) among spoil amendment treatments for all species combined. Treatment codes: $+\mathrm{P},+\mathrm{F}=$ addition of peat or fertilizer, respectively; $-\mathrm{P},-\mathrm{F}=$ absence of peat or fertilizer, respectively.

\section{Discussion}

Results show that sundial lupine exhibited the greatest growth among species and was second only to Illinois bundleflower in germination success $(21 \%)$, and therefore it should be considered a potential candidate for the reclamation of sand mines. Interestingly, this germination success is considerably lower than observations in field trials ( $-80 \%$; St. Mary 2007, Pavlovic and Grundel 2009), suggesting that sundial lupine may exhibit better establishment under field conditions compared to greenhouse conditions.

Other practitioners have had success using sundial lupine for the revegetation of mine spoils due, in part, to its nitrogen fixing ability. The subsequent addition of plant-available nitrogen $\left(\mathrm{NH}_{4}+\right.$ and $\left.\mathrm{NO}_{3}-\right)$ to the soil through leaf decomposition results in up to $295 \mathrm{~kg} / \mathrm{ha}$ of additional soil nitrogen per yr and can facilitate the establishment of other species on mine spoils (Jefferies et al. 1981).

Another benefit of sundial lupine is its use as a larval food source for the federally endangered Karner blue butterfly (Plebejus melissa samuelis; Smallidge et al. 1996, Grundel et al. 1998), which has historically occupied the barrens and savannas of the Great Lakes region. Although habitat limitation is only one of several factors limiting the distribution of Karner blue butterfly populations (Andow et al. 1994), revegetating sand mine sites in the Great Lakes region with sundial lupine can ameliorate habitat loss and may ultimately contribute to Karner blue butterfly conservation and management efforts.

Although we recommend sundial lupine for sand mine reclamation, it is not without potential disadvantages. In low-light environments, sundial lupine exhibits lower abundance, growth, and survival (Smallidge et al. 1996, Grundel et al. 1998, Pavlovic and Grundel 2009). Under more hospitable growing conditions, congeners of sundial lupine [i.e. yellow bush lupine (L. arboreus)] have been shown to inhibit the growth of other species through shading. Therefore periodic burning or mowing may be required to reduce its competitive effect on other plants (Gosling 2005). Yellow bush lupine also elevates soil fertility; this coupled with its frequent death produces open, nitrogen enriched patches that are ideal sites for colonization by non-native grasses and forbs (Marons and Connors 1996). Therefore, given its ability to increase soil nitrogen, sundial lupine, and our other legume species Illinois bundleflower, could facilitate the establishment of undesirable plant species.
Illinois bundleflower should also be considered a candidate species for revegetation efforts based on its high average germination success $(39 \%)$ and relatively high shoot growth. Other researchers have observed much higher germination success in laboratory settings (i.e. 96\%; Call 1985), while others have found lower or similar germination success in field trials (i.e. 4-44\%; Dovel 1990) suggesting that site-specific evaluation of germination success may be necessary prior to large scale revegetation efforts.

Another benefit to Illinois bundleflower is its ability to fix nitrogen, which can facilitate the establishment of other species in low nutrient environments where ecosystem development is dependent upon the accumulation of nitrogen to enable the growth of non-fixing species (Crocker and Major 1955). Soil nitrogen deficiency is a major factor limiting plant growth on spoils produced from the extraction of minerals. In nutrient poor soils, legumes have been shown to perform well when compared to non-legume species (Elias and Chadwick 1979, Imsande and Touraine 1994). In high soil nitrogen environments, legumes exhibit reduced nitrogen-fixing abilities (Lang et al. 1993, Rubio Arias et al.1999) which would limit the facilitative effect by legumes.

The 2 non-legume species evaluated in our study did not exhibit high levels of germination or growth. Despite low growth, however, results show that the addition of peat had a significantly positive impact on little bluestem growth. Indian grass also exhibited greater growth in the presence of peat compared to growth without peat, but these results were not statistically significant (Table 2). Results may be due, in part, to spoil $\mathrm{pH}$. Soil $\mathrm{pH}$ of $\geq 5.5$ is recommended for optimal growth of warm-season grasses (Dickerson et al. 1998). Spoil amended with peat exhibited a mean $\mathrm{pH}$ of 6.2 while unamended spoil had a $\mathrm{pH}$ of 8.2, suggesting that peat amended spoil 
provides a more favorable soil $\mathrm{pH}$ for the growth of these grasses.

Despite the poor results exhibited here, warm-season grasses can be an important component of sand mine reclamation. Gaffney and Dickerson (1987) found that warm-season grasses were the most successful in revegetating former sand mines over an $8 \mathrm{yr}$ period, compared to legumes and cool-season grasses. Previous research also suggests that warm-season grasses may perform better than observed here. From a prescribed fire management perspective, a significant proportion of grasses are necessary for facilitating effective fires in plant community restoration projects (Packard and Mutel 1997). Furthermore, bunch grasses are effective barriers against soil erosion (Dabney et al. 1993, Dewald et al. 1996).

Among spoil amendments, peat exhibited the greatest positive effect on germination, root, shoot, and total biomass. Peat had a significant effect on sundial lupine and Illinois bundleflower germination and positively affected the growth of Illinois bundleflower and little bluestem. The positive impact of peat may be attributed to an increase in soil porosity and water holding capacity when peat is added to sandy soil (Sjors 1980, Ling et al. 2005). Peat also increased mean spoil acidity; however, the addition of peat did not change acidity beyond the tolerable range for most vascular plants (i.e. $\mathrm{pH}$ 3.5-8.5; Larcher 1995). While our study did not separate the individual effects of $\mathrm{pH}$ and water holding capacity on plant growth, our results indicate that any negative impact on growth that may have occurred from acidification by peat was apparently eclipsed by the overall positive impact by peat.

Although our results show that peat moss may promote initial growth and establishment of plant species used in sand mine revegetation efforts, we do not recommend peat as a spoil amendment due to negative environmental effects. Globally, the number of peat bogs has decreased substantially due to peat harvest which results in significant long term impacts on regional plant and animal diversity (Rochefort 2000, Mitchell et al. 2002, Suret et al. 2002). The loss of these ecosystems also results in the loss of important carbon sequestration sites. Peatlands are historic importers of $\mathrm{CO}_{2}$ and represent a major global source of stored carbon (Gorham 1991). Peat mining decreases carbon sequestration capacity by up to $37 \%$ and effectively transforms these areas from carbon sinks to carbon sources (Heathwaite 1993, Cleary et al. 2005).

Rather than focusing on peat as a specific water holding soil amendment, we instead stress the importance of water retention in sandy mine spoils and suggest the use of alternative amendments to peat that are functionally equivalent. Alternatives include coconut fibers, green compost such as grass clippings, leaves, pumice, pine bark, sewage sludge, and de-inking sludge (Fierro et al. 1999, MacDonald et al. 2003, Larcher and Scariot 2010). Coconut coir dust ("cocopeat") is an abundant agricultural by-product that increases soil water availability when incorporated into xeric soils (Awang et al. 2009). Similarly, paper de-inking sludge positively impacts plant growth due to increases in soil water retention and bulk density (Fierro et al. 1999). Fertilizer did not significantly improve germination of any species; however, it did positively impact shoot and total biomass for Illinois bundleflower and Indian grass (both alone and in conjunction with peat for Illinois bundleflower). Further, an examination of shoot:root ratios indicate that the addition of fertilizer did not result in physiological drought which can be due to excessive fertilizer application. Shoot:root ratios typically decrease in response to deficiencies in nutrients or water (Wilson 1988). In comparing shoot:root ratios between nonamended spoil to spoil amended with fertilizer, we observed an increase in this ratio indicating an absence of drought and further illustrating the positive impact of fertilizer compared to non-amended spoil.

Fierro and others (1999) also found that fertilizer increased the growth of sand dune species, while other researchers have found that germination is only enhanced in the presence of fertilizer when used in conjunction with frequent irrigation (Lichter 2000). In contrast to our results, Masters and colleagues (1993) found that fertilization increased germination of Indian grass and little bluestem, while Van Auken and others (1992) found that little bluestem grew well under high levels of soil nitrogen. Gaffney and Dickerson (1987) found that legumes did not respond to fertilizer amendments whereas our results indicate that fertilizer increased Illinois bundleflower growth both alone and in combination with peat.

Identifying species that do not require spoil amendments for growth is an important practical consideration when restoring degraded habitats that may be large, inaccessible, or may lack the necessary resources for amendment purchase and incorporation. To this end, we strengthen our recommendation of sundial lupine as a primary candidate for sand mine revegetation efforts because it exhibits positive growth responses in the absence of fertilizer or peat amendments. While we recognize the positive impacts of inorganic fertilizer on initial species establishment of Indian grass and Illinois bundleflower, we do not recommend the use of this amendment. Instead, we recommend the use of sundial lupine or other legumes as a source of soil nutrient additions due to their nitrogen fixing ability (Jefferies et al. 1981). Nutrient additions beyond those provided by legumes may promote competitive dominance by a few species and result in decreased plant community diversity over time (Tilman 1982, 1988, Stevens et al. 2006).

Furthermore, considering increases in global nitrogen emissions, the addition of inorganic fertilizer may not be necessary for plant establishment. 
Global nitrogen emissions have grown over the past $150 \mathrm{yr}$, primarily due to anthropogenic activity, from approximately $31 \mathrm{Tg} \mathrm{N}^{-1}$ in the 1860 s to a recent estimate of $124 \mathrm{Tg} \mathrm{N}^{-1}$. Total nitrogen emissions are expected to continue increasing and reach 195 $\mathrm{Tg} \mathrm{N}^{-1}$ by 2050 (Fowler et al. 2004, Galloway et al. 2004). Therefore, additional nitrogen inputs via inorganic fertilizer should be carefully considered in areas that exhibit increased nitrogen deposition.

While our results elucidate the important role particular species and spoil amendments may play in sand mine reclamation efforts, recommendations should be viewed in light of the limitations of this experiment. Our experiment evaluates seedling establishment under greenhouse conditions. Results would likely have been vastly different given a longer period of growth or if our evaluation had been conducted under field conditions. For example, while our results indicate that legumes exhibited the greatest initial growth when compared to warm-season grasses, other researchers working with little bluestem and Indian grass under field conditions found that these species eventually become dominant components of the plant community (Dickerson et al. 1998). Our experiment also controlled for other important variables including water availability, seed density, seed predation, herbivory, intra- and interspecific competition. While these variables can be difficult to control in a field environment, a practitioner can help alleviate some of the potential problems associated with these factors. For example, a field application could incorporate artificial irrigation, transplanted seedlings, seedling protection from herbivores, and site preparation and management to help reduce interspecific competition.

Species selection should also be viewed with discretion considering Illinois bundleflower and Indian grass are not typically found in sand dune habitats (Kost et al. 2010). While these species would not satisfy restoration goals where only characteristic species of sand dune plant communities are acceptable, these species provide erosion control and soil nitrogen and organic matter additions which can facilitate future colonization of more characteristic species. Furthermore, the species evaluated here should not be viewed as the only possible candidate species for revegetation efforts nor do we recommend establishing monospecific stands of any of these species. Instead, these species should be considered as potential components of a diverse native species mix.

Despite these limitations, our results are helpful in determining which species and amendment combinations are potentially useful in revegetating former sand mines or similar habitats. Specifically, sundial lupine and Illinois bundleflower are recognized as potential candidate species for revegetation efforts in mine reclamation. We further recognize the importance of incorporating soil amendments into mine spoils that help to increase soil water holding capacity.

\section{Acknowledgements}

We thank Alan Slater of Standard Sand Co., Fairmont Minerals for his support in making this project possible. We also thank Diane Laughlin and Star Santiago of the Department of Biology, Grand Valley State University (GVSU) for greenhouse assistance. Richard Rediske of GVSU-Annis Water Resources Institute conducted soil analyses. Dr. Neil MacDonald and Robert Roos provided valuable comments on an earlier draft of this manuscript. We also thank the anonymous reviewers for their insightful comments on this manuscript.

\section{References}

Albert, D.A. 2000. Borne of the Wind: An Introduction to the Ecology of Michigan Sand Dunes. Lansing MI: Michigan Natural Features Inventory.

Andow, D.A., R.J. Baker and C.P. Lane. 1994. Karner blue butterfly: A symbol of avanishing landscape. St. Paul MN: University of Minnesota Agricultural Experiment Station. Publication No. 84-1994.
Awang Y., A.S. Shaharom, R.B. Mohamad and A. Selamat. 2009. Chemical and physical characteristics of cocopeatbased media mixtures and their effects on the growth and development of Celosia cristata. American Journal of Agricultural and Biological Sciences 4: 63-71.

Ayres, Lewis, Norris and May, Inc. and M.J. Chapman. 1978. An economic study of coastalsand dune mining in Michigan. Report of Investigation No. 20. Lansing MI: Geological Survey Division.

Binkley, D. and P. Vitousek. 1991. Soil Nutrient Availability. Pages 75-96 in W. Pearcy, J.Ehleringer, H.A. Mooney, and P.W. Rundel (eds), Plant Physiological Ecology: Field Methods and Instrumentation. London: Chapman and Hall.

Bowles, M.L., M.M. Demauro, N.B. Pavlovic and R.D. Hiebert. 1990. Effects of anthropogenic disturbances on endangered and threatened plants at the Indiana Dunes National Lakeshore. Natural Areas Journal 10:187-200.

Call, C.A. 1985. Storage life of Illinois Bundleflower and Western Indigo seed. Journal of Range Management 38:500-503.

Callaway, R.M. 1995. Positive interactions among plants. Botanical Review 61:306-349.

and L.R. Walker. 1997. Competition and facilitation: A synthetic approach to interactions in plant communities. Ecology 78:1958-1965.

Choi, Y.D. and N.B. Pavlovic. 1998. Experimental restoration of native vegetation in Indiana Dunes National Lakeshore. Restoration Ecology 6:118-129.

Cleary, J., N.T. Roulet and T.R. Moore. 2005. Greenhouse gas emissions from Canadian peat extraction, 1990 2000: A life-cycle analysis. Ambio 34:456-461.

Crocker, R.L. and J. Major. 1955. Soil development in relation to vegetation and surface age at Glacier Bay, Alaska. Journal of Ecology 43:427-448.

Cummings, J., N. Reid, I. Davies and C. Grant. 2005. Adaptive restoration of sand-mined areas for biological conservation. Journal of Applied Ecology 42:160-170.

Curtis, M.J. and V.P. Claassen. 2009. Regenerating topsoil functionality in four drastically disturbed soil types by 
compost incorporation. Restoration Ecology 17:24-32.

Dabney, S.M., K.C. McGregor, L.D. Meyer, E.H. Grissinger and G.R. Foster. 1993.Vegetative barriers for runoff and sediment control. Pages 60-70 in J.K. Mitchell (ed), Integrated Resource Management and Landscape Modificationfor Environmental Protection. St. Joseph MI: American Society of Agricultural Engineers.

Dewald, C.L., J. Henry, S. Bruckerhoff, J. Ritchie, S. Dabney, D. Shepherd, J. Douglas and D. Wolf. 1996. Guidelines for establishing warm season grass hedges for erosion control Journal of Soil and Water Conservation 51:16-20.

Dickerson, J.D., D.B. Wark, D. Burgdorf, R. Maher, T. Bush, B. Poole and C. Miller. 1998. Vegetating with Native Grasses in Northeastern North America: A Manual. Syracuse NY: U.S. Department of Agriculture Natural Resources Conservation Service Plant Materials Program and Ducks Unlimited Canada.

Dovel, R.L., M.A. Hussey and E.C. Holt. 1990. Establishment and survival of Illinois Bundleflower interseeded into an established kleingrass pasture. Journal of Range Management 43:153-156.

Dytham, C. 2003. Choosing and Using Statistics: A Biologists Guide, 2nd ed. Oxford UK:Blackwell Science.

Elias, C.O. and M.J. Chadwick. 1979. Growth characteristics of grass and legume cultivars and their potential for land reclamation. Journal of Applied Ecology 16:537-544.

Enright, N. and B.B. Lamont. 1992. Survival, growth, and water relations of Banksia seedlings on a sand mine rehabilitation site and adjacent scrubhealth sites. Journal of Applied Ecology 29:663-671.

Fierro, A., D.A. Angers and C.J. Beauchamp. 1999. Restoration of ecosystem function in an abandoned sandpit: Plant and soil responses to paper de-inking sludge. Applied Ecology 36:244-253.

Fowler, D., J.B.A. Muller and L.J. Sheppard. 2004. The GaNE Programme in a global perspective. Water, Air, and Soil Pollution: Focus 4:3-8.

Gaffney, F.B. and J.A. Dickerson. 1987. Species selection for revegetating sand and gravel mines in the Northeast. Journal of Soil and Water Conservation 42: 358-361.
Galloway, J.N., F.J. Dentener, D.G. Capone, E.W. Boyer, R.W. Howarth, S.P. Seitzinger, G.P. Asner, C.C. Cleveland, P.A. Green, E.A. Holland, D.M. Karl, A.F. Michaels, J.H. Porter, A.R. Townsend and C.J. Vörösmarty. 2004. Nitrogen cycles: past, present, and future. Biogeochemistry 70: 153-226.

Gosling, P. 2005. Facilitation of Urtica dioica colonization by Lupinus arboreus on a nutrient poor mining spoil. Plant Ecology 178:141-148.

Gorham, E. 1991. Northern peatlands role in the global carbon cycle and probable responses to climatic warming. Ecological Applications 1:182-195.

Grundel, R., N.B. Pavlovic and C.L. Sulzman. 1998. The effect of canopy cover and seasonal change on host plant quality for the endangered Karner blue butterfly (LycaeidesMelissa samuelis). Oecologia 114:243-250.

Heathwaite, A.L. 1993. Disappearing peat- regenerating peat? The impact of climate change on British peatlands. Geographical Journal 159:203-208.

Imsande, J. and B. Touraine. 1994. N demand and the regulation of nitrate uptake. Plant Physiology 105: 3-7.

Jefferies, R.A., A.D. Bradshaw and P.D. Putwain. 1981. Growth, nitrogen accumulation and nitrogen transfer by legume species established on mine spoils. Applied Ecology 18:945-956.

Kost, M.A., D.A. Albert, J.G. Cohen, B.S. Slaughter, R.K. Schillo, C.R. Weber and K.A. Chapman. 2010. Natural communities of Michigan: Classification and description. Lansing MI: Natural Features Inventory. Report No. 2007-21, vers. 1.2.

Lang, P., R. Martin and M.P. Golvano. 1993. Effect of nitrate on carbon metabolism and nitrogen fixation in root nodules of Lupinus albus. Plant Physiology and Biochemistry 31:639-648.

Larcher, F. and V. Scariot. 2010. Use of partial peat substitutes in growing media for Camellia japonica production. Acta Horticulturae 885:203-207.

Larcher, W. 1995. Physiological Plant Ecology. Berlin: Springer.

Lichter, J. 2000. Colonization constraints during primary succession on coastal Lake Michigan sand dunes. Journal of Ecology 88:825-839.

Ling, Q., W. Qinping, L. Jiarui, W. Xiaowei and L. Jun. 2005. Effects of peat on water conserving properties of sandy soil. Transactions of the Chinese
Society of Agricultural Engineering 21:163-175.

MacDonald, N.W., M.T. Koetje and B.J. Perry. 2003. Native warm-season grass establishment on spotted knapweed-infested gravel mine spoils. Journal of Soil and Water Conservation 58:243-250.

Maron, J.L. and P.G. Connors. 1996. A native nitrogen-fixing shrub facilitates weed invasion. Oecologia 105:302-312.

Masters, R.A., R.B. Mitchell, K.P. Vogel and S.S. Waller. 1993. Influence of improvement practices on big bluestem and Indian grass seed production in tallgrass prairies. Journal of Range Management 46:183-188.

Maun, M.A. and I. Krajnyk 1989. Stabilization of Great Lakes sand dunes: Effect of planting time, mulches and fertilizer on seeding establishment. Journal of Coastal Research 5:791-800.

Mitchell, E.A.D., A. Buttler, P. Grosvernier, H. Rydin, A. Siegenthaler and J.M. Gobat. 2002. Contrasted effects of increased $\mathrm{N}$ and $\mathrm{CO}_{2}$ supply on two keystone species inpeatland restoration and implications for global change. Journal of Ecology 90: 529-533.

Nelson, D.W. and L.E. Sommers. 1996. Total carbon, organic carbon, and organic matter. Pages 961-1010 in D.L. Sparks (ed), Methods of Soil Analysis, Part 3, Chemical Methods. Madison WI: Soil Science Society of America.

Packard, S. and C.F. Mutel. 1997. The Tallgrass Restoration Handbook: For Prairies, Savannas and Woodlands. Washington DC: Island Press.

Palmgren, G. 2000. Sand Mine Restoration Plan: Grand Mere State Park. Lansing MI: Michigan Department of Natural Resources.

Pavlovic, N.B. and R. Grundel. 2009. Reintroduction of wild lupine ( $L$ upinus perennis L.) depends on variation in canopy, vegetation, and litter cover. Restoration Ecology 17:807-817.

Pichtel, J.R., W.A. Dick and P. Sutton. 1994. Comparison of amendments and management practices for longterm reclamation of abandoned mine lands. Journal of Environmental Quality 23:766-772.

Pregitzer, K.E. 1972. Soil Survey of Ottawa County, Michigan. Washington DC: U.S. Department of Agriculture Soil Conservation Service. 
Prosser, I.P. and S.J. Roseby. 1995. A chronosequence of rapid leaching of mixed podzol soil materials following sand mining. Geoderma 61:297-308.

Reeder, J.D. and B. Sabey. 1987. Nitrogen. Reclaiming mine spoils and overburden in the western United States. Pages 155-184 in R.D. Williams and G.E. Schuman (eds), Analytic Parameters and Procedures. Ankeny, IA: Soil Conservation Society of America.

Rochefort, L. 2000. A keystone genus in habitat restoration. The Bryologist 103:503-508.

Rubio Arias, H.O., L. de la Vega, O. Ruiz and K. Wood. 1999. Differential nodulation response and biomass yield of Alexandria clover as affected by levels of inorganic nitrogen fertilizer. Journal of Plant Nutrition 22:1233-1239.

Sjors, H. 1980. Peat on earth: multiple use or conservation. Ambio 9: 303-308.

Smallidge, P.J., D.J. Leopold and C.M. Allen. 1996. Community characteristics and vegetation management of Karner blue butterfly (Lycaeidesmelissa samuelis) habitats on rights of-way in east-central New York, USA. Journal of Applied Ecology 33:1405-1419.

Sokal, R.R. and F.J. Rolf. 1995. Biometry: The Principals and Practice of Statistics inBiological Research, 3rd ed. New York: W.H. Freeman and Company.

Stevens, C.J., N.B. Dise, D.J.G. Gowing and J.O. Mountford. 2006. Loss of forb diversity in relation to nitrogen deposition in the UK: Regional trends and potential controls. Global Change Biology 12:1823-1833.

St. Mary, M.K. 2007. A study on the effectiveness of transplanting vs. seeding of Lupinus perennis in an oak savanna regeneration site. M.S. Thesis, Bowling Green State University, Bowling Green.
Suret, C., G.L. Brun and V.N. Malet. 2002. Impact of a commercial peat moss operation on water quality and biota in a small tributary of the Richibucto River, Kent County, New Brunswick, Canada. Archives of Environmental Contamination and Toxicology 42:423-430.

Tilman, D. 1982. Resource Competition and Community Structure. Princeton NJ: Princeton University Press. 1988. Plant Strategies and the Dynamics and Structure of Plant Communities. Princeton NJ: Princeton University Press.

U.S. Department of Agriculture-Natural Resources Conservation Service (USDA-NRCS). 2011. The PLANTS Database. plants.usda.gov.

U.S. Department of Health and Human Services (USDHHS). 2008. Sand and Gravel Operator Mining Facts-2006. Washington DC: National Institute for Occupational Safety and Health. Publication No. 2008-160. www.cdc .gov/Niosh/mining/pubs/pdfs/2008160.pdf.

U.S. Geological Survey (USGS). 2010. Sand and gravel statistics in T.D. Kelly and G.R. Matos (eds), Historical Statistics for Mineral and Material Commodities in the United States. pubs .usgs.gov/ds/2005/140/

U.S. Geological Survey (USGS). 2007. The Mineral Industry of Michigan in Minerals Yearbook, Vol. II, Area Reports: Domestic. minerals.usgs.gov/minerals/ pubs/state/2007/myb22007-mi.pdf.

U.S. Lake Survey. 1952. Shoreline of the Great Lakes and Connecting Rivers. File No. 3-3284.

Van Auken, O.W., J.K. Bush and D.D. Diamond. 1992. The role of light and nutrients in determining dominance of Paspalum plicatulum Michx. and Schizachyriumscoparium (Michx.) Nash, two $\mathrm{C}_{4}$ grasses. Bulletin of the Torrey Botanical Club 119:401-406.

Wilson, J.B. 1988. Review of evidence in control of shoot:root ratio, in relation to models. Annals of Botany 61:433-499.

Todd A. Aschenbach (corresponding author), 326 Henry Hall, 1 Campus Dr., Natural Resources Management Program, Department of Biology, Grand Valley State University, Allendale, MI, aschenbt@gvsu .$e d u$.

Elizabeth Brandt, Natural Resources Management Program, Department of Biology, Grand Valley State University, Allendale, MI.

Melissa Buzzard, Natural Resources Management Program, Department of Biology, Grand Valley State University, Allendale, $M I$.

Ryan Hargreaves, Natural Resources Management Program, Department of Biology, Grand Valley State University, Allendale, MI.

Thomas Schmidt, Natural Resources Management Program, Department of Biology, Grand Valley State University, Allendale, MI.

Amanda Zwagerman, Natural Resources Management Program, Department of Biology, Grand Valley State University, Allendale, $M I$. 